\title{
SUPPLEMENTARY READING MATERIALS FOR MADRASAH LEARNERS BASED ON GENRE APPROACH
}

\author{
Riswanto \\ Institut Agama Islam Negeri (IAIN) Bengkulu \\ Jl. Raden Patah, Kelurahan Pagar Dewa, Bengkulu, Indonesia 65144 \\ Email: riswancurup@gmail.com

\section{Hanura Febriani} \\ Institut Agama Islam Negeri (IAIN) Bengkulu \\ Jl. Raden Patah, Kelurahan Pagar Dewa, Bengkulu, Indonesia 65144 \\ Email:nou_rha@yahoo.com
}

\begin{abstract}
This paper investigated analysis of supplementary reading material development using a genre-based approach which is in line with the school curriculum. It employed the procedures: need analysis, supplementary materials development, expert validation, material revision, material testing, and subsequent material revision. The data were collected by using questionnaires, interview, syllabus analysis, and field note. The analysis shows that the supplementary reading materials entitled Reading for Islamic Learners were completely developed. The supplementary reading materials were developed on student's need and school recommendation, in line with standard competence and basic competence from syllabus. They contain interesting reading passages featuring Islamic messages, delivered through colorful pictures. In addition they have various reading strategies and accompanied by evaluation tools covering: multiple choice and essay.
\end{abstract}

Keywords: Genre, Islamic Learners, Supplementary Materials.

\begin{abstract}
ABSTRAK
Artikel ini membahas hasil analisa pengembangan bahan bacaan penunjang keterampilan membaca dengan menggunakan pendekatan berbasis genre yang sejalan dengan kurikulum sekolah. Analisis dilakukan dengan menggunakan prosedur berupa: analisis kebutuhan, pengembangan materi tambahan, pengesahan abli, revisi materi, uji coba materi, dan revisi ulang materi. Data dikumpulkan dengan menggunakan angket, wawancara, analisis silabus, dan catatan lapangan. Hasil analisa menunjukkan babwa bahan bacaan penunjang yang berjudul Reading For Islamic Learners disusun secara lengkap. Bahan bacaan penunjang tersebut dikembangkan berdasarkan kebutuhan peserta didik dan rekomendasi sekolah, disusun berdasarkan standar kompetensi dan kompetensi dasar sesuai silabus. Bahan bacaan penunjang memiliki bagian bacaan yang menarik dengan pesan ajaran Islam yang dilengkapi dengan gambar berwarna. Bahan bacaan penunjang menyisipkan berbagai strategi membaca, dilengkapi dengan alat evaluasi dalam bentuk pilihan ganda dan essai.
\end{abstract}

Kata Kunci: Genre, Pelajar Islam, Materi Tambahan 


\section{INTRODUCTION}

In this modern era, most people use many kinds of materials via online and offline throughout the day. Almost all activities require us to read. The good readers comprehend what they read. Reading comprehension is regarded as the core for reading process. The latest Islamic schools/madrasah (public and private) is under the management of the Ministry of Religious Affairs that expected not only master general education but also have strong understanding of religious and moral values based on Islamic teachings. Nowadays students in Indonesia have moral degradation. By inserting Islamic themes through English materials, students are expected not only have good ability in reading but also have deep knowledge of Islamic teachings. Therefore the misunderstanding of Islamic teachings can also be avoided.

Seeing the fact that reading is a necessity, reading interest should be implanted in students' mind as early as possible and the reading comprehension must be improved. Based on the preliminary study to students in MAN (Madrasah Aliyah Negeri) 3 Malang especially in MAKBI (Madrasah Aliyah Keagamaan Bertaraf International) program, it revealed that the English material used in this school is the same as the book in other state schools, they only use general books ("Kemenag," 2014). There is not any specific reading material taking the religion theme. This is unfortunate because they are derived from religious school and sit in MAKBI program which emphasizes religion education, but they are not familiar with English Islamic themes which are proved by the questionnaires that are distributed to them. Most of the books for Islamic studies sold in the markets are for university level and quite difficult to be found. From the students' interview, they feel bored to read the activity provided in the textbook.

It is, therefore, necessary to develop supplementary reading materials which are suitable for students' need. The supplementary reading materials are expected to be able to guide students to learn the Islamic tenets through the English reading materials. To make student easier to understand the text, the reading materials should be well organized. In developing these supplementary reading materials, writer will adopt the design of Genre Based Approach (GBA).

The term genre was first introduced in the area of English Specific Purpose (ESP). The term genre also has been defined and discussed from different viewpoints. Bruce (2008) states that GBA has strength of reading or writing the skill formation, those are, 1) GBA encourages the linguistic learners to focus more on linguistics in discourse analysis, 2) this approach also enables learners to focus on elements formation or arrange a discourse 
or a text, 3) GBA encourages linguistic learners to see that linguistic component is also an essential part in a discourse. Reader's awareness in structure of a text and reader's sufficient knowledge of a text organization are argued as an important piece of the positive features which will enable the readers to be efficient (Sulistyo, 2011).

It is expected by giving the appropriate supplementary reading materials, the students' interest in reading can also be improved. So, this study was aimed to develop the supplementary reading materials based on GBA for Islamic EFL learners. This reading material book is expected to be an alternative solution for teaching reading at MAN 03 Malang especially in MAKBI Program.

The research was conducted by using research and development design (Rosenthal, 2016). The writer adapts and modifies the material development procedure model based on Borg (1981) that comprises seven steps. The procedurs are: 1) need analysis 2) selecting and sequencing the materials, 3) developing the materials, 4) expert validation, 5) revising based on expert verification, 6) try-out and evaluation from practical data, 7) final product of reading materials.

\section{DISCUSSION}

\section{The concept of Madrasah Aliyah (MA)}

Madrasah is a unit of formal education in supervision of the Minister of Religion that enforces the general and vocational schools with Islamic religion specificity encompassing Raudhatul Athfal (RA), Madrasab Ibtidaiyah (MI), Madrasah Tsanawiyah (MTs), Madrasab Aliyah (MA) and Madsarah Aliyah Kejuruan (MAK) (Regulation of the Minister of Religion No. 90 Year 2013).

MA is a unit of formal education enforcing the general education with Islamic religion specificity on the level of intermediate education as a continuation from SMP (Sekolah Menengah Pertama/Junior High School), MTs, or other forms in the same level, acknowledged the same or equal to SMP or MTs. MA consists of three levels, namely: the $10^{\text {th }}$ grade, the $11^{\text {th }}$ grade, and the $12^{\text {th }}$ grade. Education in MA aims to increase students' knowledge to continue their education at a higher level, to develop themselves in line with the development of science, technology and art imbued with Islamic teachings, and to increase students' ability as members of society in relation hold forth with the social environment, culture and natural surroundings (Regulation of the Minister of Religion No. 90 Year 2013).

Curriculum of MA comprises general contents, academic interest contents, and cross-interest choice contents or art deepening. The general contents consist of religion education, civic education, linguistics, mathematics, natural science, social science, art and culture, bodily education 
and sport, skill, and local contents. Subject of religion at MA consists of alQur'an and Hadith, Akidab-Akblak (faith-character), Fiqih, and Islamic Culture History, while linguistic subjects developed at MA are Indonesian, English, and Arabic (Regulation of the Minister of Religion No. 90 Year 2013).

\section{Genre-Based Approach in Teaching Learning Process}

Many experts try to introduce and present their concepts about genre. Genre is a term for grouping texts together, representing how writers typically use a language to respond to recurring situations (Hyland, 2007). Nunan also states that genre is a purposeful, socially constructed, oral or written communicative event, such as narrative, a casual conversation, a poem, a recipe, or a description (Nunan, 1999). The application of GBA in the classroom is shown in the Table 1.

Table 1. The Application of Genre-Based Approach in the Classroom

\begin{tabular}{|c|c|c|}
\hline No. & $\begin{array}{l}\text { Stages of } \\
\text { GBA }\end{array}$ & Activities \\
\hline 1. & $\begin{array}{l}\text { Building } \\
\text { the } \\
\text { context. }\end{array}$ & $\begin{array}{l}\text { Purpose of text- Social purpose of the text } \\
\text { Register Field building } \\
\text { What is the text about? } \\
\text { What do students already know about it? } \\
\text { What experiences, activities will be part of the } \\
\text { exploration? } \\
\text { Information from the activities is organized } \\
\text { By using the related images and realism e.g.: } \\
\text { photographs, video, illustration, objects, and internet. } \\
\text { Brainstorming vocabulary from images, discussing } \\
\text { topic including comparison with different culture and } \\
\text { access issues. } \\
\text { Research activities together with material on topic. } \\
\text { Establishing tenor (level of involvement between } \\
\text { reader and writer in terms of contact and emotional } \\
\text { charge). } \\
\text { Establishing mode (distance between reader/writer in } \\
\text { terms of time and space). }\end{array}$ \\
\hline 2. & $\begin{array}{l}\text { Modelling/ } \\
\text { deconstructing } \\
\text { the text. }\end{array}$ & $\begin{array}{l}\text { Text structure. } \\
\text { The stages (narrative). } \\
\text { The function of the stages e.g. sequencing a text that } \\
\text { has been cut up into stages. } \\
\text { Language features } \\
\text { Close to focus on a particular language feature } \\
\text { Learners collect examples of a language feature, e.g. } \\
\text { list of preposition, phrases, modal verbs, key }\end{array}$ \\
\hline
\end{tabular}




\begin{tabular}{|c|c|c|}
\hline & & $\begin{array}{l}\text { vocabulary } \\
\text { Jigsaw activities }\end{array}$ \\
\hline 3. & $\begin{array}{l}\text { Joint } \\
\text { construction of } \\
\text { the text. }\end{array}$ & $\begin{array}{l}\text { Activities focusing on aparticular strategy (e.g. using } \\
\text { appropriate gestures, skimming, making notes). } \\
\text { Role play of text in groups dictogloss } \\
\text { Information gap activities to construct a text Listening } \\
\text { to a text together and acting on it Teacher acting as a } \\
\text { scribe and prompt while class jointly creates a written } \\
\text { text in groups, Constructing or completing a text as a } \\
\text { class or in groups, editing a text draft. }\end{array}$ \\
\hline 4. & $\begin{array}{l}\text { Independent } \\
\text { construction of } \\
\text { the text }\end{array}$ & $\begin{array}{l}\text { Learners consult the teachers and peers throughout } \\
\text { the process. } \\
\text { Drafts are edited, reworked and proofread }\end{array}$ \\
\hline
\end{tabular}

\section{Model of Development}

This research and its' development use the qualitative approach to find out the specific style in English reading materials based on KTSP curriculum and the environment of madrasah. The developed materials were designed in line with the syllabus used in MAKBI class and the environment of madrasah. The developed materials were in the form of supplementary materials which focus on the reading activities. In accordance with the students' needs from the result of need analysis, the material was developed by using GBA and integrating Islamic themes.

\section{Need Analysis}

To gain the data regarding the use of English book which was previously used at MAN 3 Malang, the questionnaires were spread to the $7^{\text {th }}$ grade students and interviewed the English support teacher in the $7^{\text {th }}$ grade. The data acquired are presented below.

\section{Student's Opinions}

The author conducted checklist to get data of student's opinion of the previous book. There are some weaknesses from the previously used book. Students' opinions concerning the weakness of the previously used English book can be seen in the Table 2 .

Table 2. The Weakness Criteria of the Existing Book.

\begin{tabular}{ll}
\hline No. & \multicolumn{1}{c}{ Criteria of the Weakness } \\
\hline a. & $\begin{array}{l}\text { The textbook was not interesting and not attractive in form of layout, } \\
\text { illustration and picture where they are in form of printed greyscale. }\end{array}$ \\
\hline b. & $\begin{array}{l}\text { The material in the existing textbook did not provide the appropriate } \\
\text { context and situation of the MAKBI program. So that both students and }\end{array}$ \\
\hline
\end{tabular}




\begin{tabular}{ll}
\hline & teacher are suggested making the supplementary materials which include \\
Islamic tenets. \\
\hline c. $\quad \begin{array}{l}\text { The textbook had less activities that can encourage students' motivation } \\
\text { especially in reading. }\end{array}$ \\
\hline d. $\quad \begin{array}{l}\text { The existing material had less innovation in reading activity so that the } \\
\text { students felt bored. }\end{array}$ \\
\hline e. $\quad \begin{array}{l}\text { The existing material had less vocabulary building. Most of the students } \\
\text { said that it was important since it was needed to comprehend the text } \\
\text { even one student said that it was important because in UAN there were } \\
\text { some questions of vocabulary in form of antonym, synonym and } \\
\text { meaning. }\end{array}$ \\
\hline The textbook did not provide fluency practice in reading skill. \\
\hline
\end{tabular}

2. Students' responses

To gain the data of students' responses towards the English book, there spread the questionnaires which contain 10 aspects of question as seen in the Table 3. Students' responses are made in form of percent.

Table 3. Students' responses of the Existing Book

\begin{tabular}{lllcc}
\hline No & \multicolumn{1}{c}{ Indicators } & Responses & $\begin{array}{c}\text { Total of } \\
\text { students }\end{array}$ & $\begin{array}{c}\text { Percentage } \\
\mathbf{( \% )}\end{array}$ \\
\hline a. & Students' interest & Very interested & 5 & 23,8 \\
& in learning & Interested & 11 & 52,4 \\
& English & Less interested & 5 & 23,8 \\
& & Not interested & 0 & 0,0 \\
\hline b. & Students' opinion & Very important & 8 & 38,1 \\
& on reading & Important & 13 & 61,9 \\
& & Less important & 0 & 0,0 \\
& & Not important & 0 & 0,0 \\
\hline c. & Students' interest & Very interested & 1 & 4,8 \\
& in reading & Interested & 12 & 57,1 \\
& & Less interested & 7 & 33,3 \\
& & Not interested & 1 & 4,8 \\
\hline d. & Students' & Very familiar & 1 & 4,8 \\
& familiarity of the & Familiar & 4 & 19,0 \\
& Islamic & Less familiar & 14 & 66,7 \\
& material & Not familiar & 2 & 9,5 \\
\hline e. & Students' opinion & Needed very & 11 & 52,4 \\
& & & &
\end{tabular}




\begin{tabular}{|c|c|c|c|c|}
\hline & \multirow{4}{*}{$\begin{array}{l}\text { on the need of } \\
\text { Islamic } \\
\text { knowledge in the } \\
\text { reading contents }\end{array}$} & \multicolumn{3}{|l|}{ much } \\
\hline & & Needed & 9 & 42,9 \\
\hline & & Needed less & 1 & 4,8 \\
\hline & & Not needed & 0 & 0,0 \\
\hline \multirow[t]{4}{*}{ f. } & \multirow{4}{*}{$\begin{array}{l}\text { Students' } \\
\text { opinions of the } \\
\text { Islamic } \\
\text { materials on the } \\
\text { previous book }\end{array}$} & & 0 & 0,0 \\
\hline & & & 0 & 0,0 \\
\hline & & & 16 & 76,2 \\
\hline & & Very poor & 5 & 23,8 \\
\hline \multirow[t]{4}{*}{ g. } & \multirow{4}{*}{$\begin{array}{l}\text { Students' } \\
\text { opinions on the } \\
\text { availability } \\
\text { of reading text for } \\
\text { Islamic learners }\end{array}$} & $\begin{array}{l}\text { Very Difficult to } \\
\text { get }\end{array}$ & 4 & 19,0 \\
\hline & & Difficult to get & 16 & 76,2 \\
\hline & & Easy to get & 1 & 4,8 \\
\hline & & Very easy to get & 0 & 0,0 \\
\hline \multirow[t]{4}{*}{ h. } & \multirow{4}{*}{$\begin{array}{l}\text { Students' } \\
\text { opinions on the } \\
\text { need for } \\
\text { the development } \\
\text { of reading } \\
\text { materials }\end{array}$} & Really needed & 5 & 23,8 \\
\hline & & Needed & 14 & 66,7 \\
\hline & & Needed less & 1 & 4,8 \\
\hline & & Not needed & 1 & 4,8 \\
\hline \multirow[t]{4}{*}{ i. } & \multirow{4}{*}{$\begin{array}{l}\text { Students' } \\
\text { opinions on the } \\
\text { illustration }\end{array}$} & Really needed & 12 & 57,1 \\
\hline & & Needed & 6 & 28,6 \\
\hline & & Needed less & 3 & 14,3 \\
\hline & & Not needed & 0 & 0,0 \\
\hline \multirow[t]{4}{*}{ j. } & \multirow{4}{*}{$\begin{array}{l}\text { Students' } \\
\text { preference on the } \\
\text { illustration }\end{array}$} & Colorful pictures & 10 & 47,6 \\
\hline & & $\begin{array}{l}\text { Black and white } \\
\text { pictures }\end{array}$ & 0 & 0,0 \\
\hline & & Colorful photo & 11 & 52,4 \\
\hline & & Etc & 0 & 0,0 \\
\hline
\end{tabular}

3. Teacher's Opinion concerning the Use of the Previous English Book

To gain the data of teachers' opinion regarding the use of previously used English book, there conducted an interview. From the results of interview, the teacher explained that the existing books they used in the learning process were good. However, in form of reading material the teacher said that the existing book could not develop students' competence in their own field; whereas, MAKBI program was prepared to create religious students who could spread out the spirit of Islam any where. So that the teachers were suggested developing a supplementary reading materials involving the Islamic messages expected to develop students' knowledge of Islam as well as to improve their attitudes. 
Based on the teacher's suggestion, the topic taught should also be various and appropriate for students. They might come from news, article, essay, etc. The book should provide the clear assignments and effective activities to improve students' reading comprehension; such as grouping, discussing, making a fun reading activity, and varieties of comprehension assignments. A teacher also advised including some hadith or Surah in order to deepen the feel of Muslim.

\section{Selecting and Sequencing the Materials}

The standard competence and basic competence of reading for the $11^{\text {th }}$ grade students of MAN 03 Malang stated in this syllabus are used as the basis in arranging the developed materials in this research.

The author organized a mapping material as a guide to make a systematic content of material. The mapping material is shown in the Table 4.

Table 4. Material Mapping.

\begin{tabular}{|c|c|c|c|c|}
\hline No. & Genre & Topic & Activities & $\begin{array}{c}\text { Competence and } \\
\text { learning objectives }\end{array}$ \\
\hline 1. & Narrative & $\begin{array}{l}\text { - Alibaba and } \\
\text { the Forty } \\
\text { thieves } \\
\text { - Queen of } \\
\text { Arabia and } \\
\text { the three } \\
\text { Sheiks } \\
\text { - The story of } \\
\text { Zam-zam } \\
\text { water } \\
\text { - Human's } \\
\text { kindness in } \\
\text { Islam }\end{array}$ & $\begin{array}{l}\text { - Getting started } \\
\text { Brainstorming } \\
\text { - Reading activities } \\
\text { Let's read aloud } \\
\text { Explanation Let's } \\
\text { discuss } \\
\text { Fun reading } \\
\text { activity } \\
\text { Joint construction } \\
\text { of text } \\
\text { - Expansion } \\
\text { Let's have fun } \\
\text { Independent } \\
\text { construction of } \\
\text { text } \\
\text { Muslim Corner } \\
\text { - Reading } \\
\text { comprehension } \\
\text { Task } \\
\text { - Reflection }\end{array}$ & $\begin{array}{l}\text { - Student will be } \\
\text { able to } \\
\text { comprehend the } \\
\text { narrative text } \\
\text { - Students will be } \\
\text { able to identify the } \\
\text { structure of a } \\
\text { narrative } \\
\text { - Students will be } \\
\text { able to read aloud } \\
\text { narrative text with } \\
\text { good } \\
\text { pronunciation } \\
\text { - Students will be } \\
\text { able to respond to } \\
\text { the narrative text } \\
\text { in some kinds of } \\
\text { form } \\
\text { - Students can } \\
\text { answer the reading } \\
\text { comprehension } \\
\text { questions }\end{array}$ \\
\hline
\end{tabular}




\begin{tabular}{|c|c|c|c|c|}
\hline 2. & Spoof & $\begin{array}{l}\text { - The very } \\
\text { Pious } \\
\text { husband } \\
\text { - The Iman of } \\
\text { the lady } \\
\text { - A bumpy } \\
\text { flight } \\
\text { - The series of } \\
\text { Abunawas }\end{array}$ & $\begin{array}{l}\text { - Getting started } \\
\text { Brainstorming } \\
\text { Let's read aloud } \\
\text { Explanation } \\
\text { - Reading activities } \\
\text { - Fun reading } \\
\text { Joint construction } \\
\text { of text } \\
\text { - Expansion } \\
\text { Let's have fun } \\
\text { Independent } \\
\text { construction of } \\
\text { text } \\
\text { Muslim viewpoint } \\
\text { - Reading } \\
\text { comprehension } \\
\text { Task } \\
\text { - Reflection }\end{array}$ & $\begin{array}{l}\text { - Student will be } \\
\text { able to } \\
\text { comprehend } \\
\text { spoof text } \\
\text { - Student will be } \\
\text { able to identify the } \\
\text { characteristic of } \\
\text { spoof text } \\
\text { - Students will be } \\
\text { able to Respond } \\
\text { to the spoof text } \\
\text { from various } \\
\text { kinds of form } \\
\text { - Students can } \\
\text { answer the reading } \\
\text { comprehension } \\
\text { questions }\end{array}$ \\
\hline 3. & $\begin{array}{l}\text { Hortatory } \\
\text { Exposition } \\
\text { text }\end{array}$ & $\begin{array}{l}\text { - Let's wear } \\
\text { hijab } \\
\text { - Healthy life } \\
\text { - Do we } \\
\text { Muslim not } \\
\text { celebrate } \\
\text { Valentine's } \\
\text { Day } \\
\text { - Drinking non- } \\
\text { Homogenized } \\
\text { milk is } \\
\text { healthier than } \\
\text { drinking } \\
\text { homogenized } \\
\text { Milk } \\
\text { - Zakat }\end{array}$ & $\begin{array}{l}\text { - Getting started } \\
\text { Brainstorming } \\
\text { - Reading activities } \\
\text { Let's read aloud } \\
\text { Explanation } \\
\text { Let's discuss Fun } \\
\text { reading } \\
\text { Joint construction } \\
\text { of text } \\
\text { - Expansion } \\
\text { Let's have fun } \\
\text { Independent } \\
\text { construction of } \\
\text { text } \\
\text { Muslim viewpoint } \\
\text { Reading } \\
\text { comprehension } \\
\text { Task } \\
\text { - Reflection } \\
\end{array}$ & $\begin{array}{l}\text { - Students will be } \\
\text { able to } \\
\text { comprehend the } \\
\text { hortatory text } \\
\text { - Students will have } \\
\text { a good fluency } \\
\text { and accuracy in } \\
\text { reading hortatory } \\
\text { text } \\
\text { - Students will be } \\
\text { able to Respond } \\
\text { to kinds of } \\
\text { hortatory text in } \\
\text { life }\end{array}$ \\
\hline
\end{tabular}

\section{Developing Materials}

The draft of supplementary materials development focuses on the reading activity. It is developed based on GBA which is suitable to its curriculum where it still use the KTSP curriculum and is arranged based on 
the standard competence and basic competence of the syllabus in senior high school of MAN 03 Malang especially in the $11^{\text {th }}$ grade. The supplementary materials included three chapters and the objective of the topic was stated at the beginning. The topic contents were chosen under the consideration related to the students' need and interest, teacher's suggestion and also syllabus. Those three chapters are narrative text, spoof text and hortatory exposition text.

\section{Expert Validation}

After finishing the first draft of the developed supplementary reading materials, the author validated the draft to the experts. The author choses one of the English lecturers of UNISMA as the first expert. First validator focused on Islamic text, teaching a reading strategy, activity and the appropriateness of the word or punctuation.

For the evaluation on the content, generally, the expert said that the developed materials were good and appropriate to be implemented in teaching and learning process of the English reading, but for one topic entitled Islam and Herraclius that the author took from internet, the expert said that it was wrong story and could not be inserted because it was created to obscure Islamic messages, while the right story was entitled Islam and Herraclius. Then the author changed the story into the story of zam-zam water with the agreement from the expert. He said that it was a good story that some of the students might not have read it yet. The expert also suggested adding a colorful picture that could attract students to read especially for the long passage. Then the author completed the story with picture. In this case, one story entitled Alibaba and forty thieves, the author put a series of picture for each main idea in order to attract students' interest and avoid them from being bored of the text because it was a long story, while at first the researcher only took one picture in the story.

Then the expert gave an evaluation to each first chapter where the researcher made a competence of each topic, but the expert suggested changing it into the objectives. The expert said that most of objectives that researcher made were good, but some others were not suitable for the reading competence such as using the expressions of love and sadness and enjoying reading narrative. It was changed to comprehend kinds of narrative text and to respond to the kinds of narrative text. For the aspect of teaching strategy, generally the expert said that it was interesting where the researcher put various reading strategies, but for the part of KWL (Know, Want to Know, Learned) strategy he gave an instruction to read some references again to make sure that the strategy could be used for certain genre, and from various references the researcher saw that KWL could be used for narrative 
text. The instruction that the researcher wrote related to KWL chart should also be rearranged because at first the researcher only wrote brainstorming, but the expert said that the researcher should determine the topic and write a good instruction. Therefore, the researcher rearranged a new instruction. It also happened to think of pair share strategy where the researcher forgot to put on the topic.

Next for the instruction, the expert evaluated some instructions that he said are not yet clear, such as writing your own Islamic narrative that you may know, revising it to reread the story of Alibaba, and trying to retell the story with your own words using the guidance below. So he suggested that the researcher should pay high attention to the instruction in order not to make students confused with the task.

In one topic on fun reading activity, the expert said that the researcher made an unclear activity where in this case the researcher asked students to collect some words and make them into narrative story in which it did not represent reading, but tended to be writing. Therefore, he suggested changing it into jigsaw reading.

In part of the use of punctuation and grammar, the expert said that it still had many mistakes, so the researcher had to check it again, for example the use of nominal and verbal sentence, singular and plural. For the last aspect validated by the expert is GBA principles. The expert said that the developed materials were well organized, but the researcher should make a clear activity related to joint construction of the text and independent construction of the text.

The second expert in this developed material is one of the experienced English teachers in MAN 03 Malang. The main point that is validated by the second expert is the compatibility of the text, vocabulary, illustration to the students of MAN 03 Malang. The result of the validation is as follows: the expert said that the layout was structurally clear and attractive, but he suggested changing the cover related to reading activity, while the researcher at first just put the students togetherness in the school. In the aspect of typing, the author gave the comments to make it consistent. However, he also gave a critic about the text that was not consistent in form of spacing and the font used in puzzle that was supposed to be clear, not too small.

From the part of the content, the expert said that generally all the texts had been good but he suggested adding Muslim viewpoint containing some Islamic knowledge and Sürah that can broaden student's knowledge of Islam and also adding their mastery of Surah which they can use for their next activity. It is also in line with students of MAKBI activity in Ma'bad where they should also memorize the Surah. Then he said that it was better to take a 
topic related to adolescent word. Like the first expert, he also suggested completing the text with a good picture to attract students' interest.

In the part of vocabulary and the materials development, the expert said that vocabulary was appropriate for the target learners. The existence of glossary can help students comprehend the text. He agreed to add vocabulary building in the material to train students understanding about new words and train them becoming a strategic reader who can guess the difficult words from the context.

The good point, according to him, was also related to various activities that the author made; the exercises promoted students' knowledge of the topic and their reading skill; but the activities were not well organized so it needed reorganizing.

The expert suggested the author to be careful of grammar and punctuation on each topic because he found many mistakes on each unit. The mistakes which were frequently made by researcher were the wrong capitalization, singular and plural noun, determinant, and auxiliary form in question. In page 12 the researcher first said "fill the blank with the word in the bracket", while the expert said "fill the blank with the word in the table". Fortunately, he opened hand to help researcher correct the mistakes again and again. In line with the first expert, he has a lot of critics in the part of instruction. He said that some of them are still not clear yet so that the researcher should check again and make up the good one. For the aspect of teaching strategy, generally the expert was very interested. Teaching strategy could motivate the students to be more active in the reading activities.

The expert also suggested the researcher to be careful in explaining the example of Abu Nawas story that existed in the second unit. The expert suggested not making the students just laugh at Abu Nawas due to his joking, because Abu Nawas is famous in Muslim people. Therefore, the researcher should be very careful in choosing the appropriate topic from Abu Nawas series.

Next, in the part of the example, the expert said that it was very good because the researcher explained it clearly. It can be seen from the text that the researcher elaborated the language feature well so that the students can know the part of the story and the language feature of it more easily.

Finally, the revision was conducted based on the correction and suggestion from both experts in order to make a better final product.

\section{Revision of the Product}

The next step of the research was the expert validation. When the first draft was ready, the researcher consulted it to the experts in order to be evaluated to make sure that the supplementary materials are valid to be 
applied to the students. All of suggestions from the experts for these developed materials were very useful in order to make these developed materials better. All of aspects concerning the weaknesses of the developed supplementary materials had been redesigned based on the suggestions and had been validated by both of experts. Then, the materials are improved and ready to be tried out.

\section{Try-Out}

In order to obtain the empirical validity of the material, the researcher conducted a tryout. Because of the limitation in the form of time and permission, the researcher only conducted the tryout for one unit with two meetings. Based on the try-out process, the data were gathered by using questionnaires for the students which were focused on twelve points that represent students' opinion about the developed English reading materials.

Those twelve points are about the appropriateness of the instructional goal, the attractiveness of the material, students' motivation to learn the material, the usefulness of the materials in Islamic context, the students' need, the usefulness of the material in developing reading comprehension, the suitability of the example, level of comprehending the material, the instruction, the material and the development of Islamic horizon, the attractiveness of the illustration and the last is students' reflection.

Table 5. Students' Opinion about the Developed English Reading Materials

\begin{tabular}{|c|c|c|c|c|c|c|c|}
\hline \multirow{2}{*}{ No } & \multirow{2}{*}{ Criteria } & \multicolumn{6}{|c|}{ Students' answer } \\
\hline & & Yes & $\%$ & Partly & $\%$ & No & $\%$ \\
\hline 1. & $\begin{array}{l}\text { The appropriateness of } \\
\text { the instructional goal. }\end{array}$ & 18 & 85.71 & 3 & 14.29 & 0 & 0 \\
\hline 2. & $\begin{array}{l}\text { The attractiveness of the } \\
\text { material. }\end{array}$ & 20 & 95.24 & 1 & 4.76 & 0 & 0 \\
\hline 3. & $\begin{array}{l}\text { Students' motivation to } \\
\text { learn the material. }\end{array}$ & 15 & 71.43 & 6 & 28.57 & 0 & 0 \\
\hline 4. & $\begin{array}{l}\text { The usefulness of the } \\
\text { materials in Islamic } \\
\text { context. }\end{array}$ & 17 & 80.95 & 4 & 19.05 & 0 & 0 \\
\hline 5. & $\begin{array}{l}\text { The students' need of the } \\
\text { material. }\end{array}$ & 19 & 90.48 & 2 & 9.52 & 0 & 0 \\
\hline 6. & $\begin{array}{l}\text { The usefulness of the } \\
\text { material in developing } \\
\text { reading comprehension. }\end{array}$ & 16 & 76.19 & 4 & 19.05 & 1 & 4.76 \\
\hline
\end{tabular}




\begin{tabular}{|c|c|c|c|c|c|c|c|}
\hline 7. & $\begin{array}{l}\text { The suitability of the } \\
\text { example. }\end{array}$ & 18 & 85.71 & 3 & 14.29 & 0 & 0 \\
\hline 8. & $\begin{array}{l}\text { Level of comprehending } \\
\text { the material. }\end{array}$ & 13 & 61.90 & 7 & 33.33 & 1 & 4.76 \\
\hline 9. & $\begin{array}{l}\text { The understanding of the } \\
\text { instruction. }\end{array}$ & 13 & 61.90 & 6 & 28.57 & 2 & 9.52 \\
\hline 10. & $\begin{array}{l}\text { Whether the material can } \\
\text { develop their islamic } \\
\text { horizon. }\end{array}$ & 17 & 80.95 & 4 & 19.05 & 0 & 0 \\
\hline 11. & $\begin{array}{l}\text { The atrractiveness of } \\
\text { illustration. }\end{array}$ & 12 & 57.14 & 8 & 38.10 & 1 & 4.76 \\
\hline 12. & $\begin{array}{l}\text { The usefulness of } \\
\text { evaluation. }\end{array}$ & 14 & 66.67 & 4 & 19.05 & 3 & 14.29 \\
\hline
\end{tabular}

The data in the Table 5 above shows students' positive attitudes towards English reading materials made by researcher. The students' positive attitudes which were shown by eight aspects and were inquired to students were positively responded by answering more than $70 \%$. The eight aspects are the appropriateness of the instructional goal, the attractiveness of the material, students' motivation to learn the material, the usefulness of the materials in Islamic context, the students' need, the usefulness of the material in developing the reading comprehension, the suitability of the example, the material and the development of Islamic horizon.

While on four other aspects, the students thought that the English reading material had not fully met the aspects of level of comprehending the material, the understanding of the instruction, the attractiveness of illustration, and the usefulness of evaluation. The students' opinions above are then enacted a consideration by researcher to improve the English reading materials.

\section{Revision from Try-Out}

After having try-out and collecting the data from the questionnaires, the researcher revised the lack and weaknesses of the developed materials. Those lacks or weaknesses from this product are such as the topic of the text, mistyping, misspelling, unclear instruction, grammar focus and etc.

\section{Final Product}

After all the phases has been passed, the developed materials were completely developed. The final product of this development was accommodated for the $11^{\text {th }}$ grade in the $2^{\text {nd }}$ semester of MAKBI program. The textbook is completely arranged entitled Reading For Islamic Learners 
because this book was created especially for the Islamic learners. The book contains three units includes three genres with various kinds of passage.

This reading textbook is developed based on students' need, school recommendation, and it was arranged based on standard competence and basic competence from syllabus. Interesting reading passage with Islamic message was designed not only to improve student's quality in reading but also to create Muslims' good attitude. The text is also completed by colorful pictures related to the topic in the hope of being able to attract student's interest to reading, and the researcher also inserted some various strategies of reading in order to increase student's comprehension skill and to check their mastery in reading comprehension as well as to show their competence. This textbook also provides some various exercises such as multiple choice, completion, essay, etc. This book is also completed by Muslim viewpoint aiming to develop students' knowledge of Islam.

\section{CONCLUSION}

The developed materials as supplementary materials which supplement and cover the lack of main book of the English subject which focuses on reading skill for MAN 03 Malang based on GBA has been compiled. These developed materials aim to help the teachers in teaching reading, and hopefully it can convey Islamic messages to the students that rarely exist on the main book in order to solve students' problems in reading. The students also showed the positive attitudes towards the English reading materials which had been successfully made by the researcher.

\section{BIBLIOGRAPHY}

Borg, W. R. (1981). Applying educational research: a practical guide for teacher. USA: Longman.

Bruce, I. (2008). Academic writing and genre. Great Britain: Biddles.

Hyland, K. (2007). Genre pedagogy: language, literacy and 12 writing instruction. Journal of Second Language Writing, 16, 148-164. Retrieved from https:// doi.org/10.1016/j.jslw.2007.07.005

Nunan, D. (1999). Second language teaching and learning. Boston: Heinle \& Heinle Publisher.

Nuttall, C. (1982). Teaching reading skill. London: Parkway Group.

PISA. (2012, July 20). Pisa 2012 result : which country does best at reading, math, and science? Retrieved from The Guardian: http://www.theguardian.com/news/datablog/2013/dec/03/pisaresults-country-best-reading-maths-science.

Kemenag. (2014). Retrieved from https://www.kemenag.go.id/. 
Rohmah, Z. (2012). Incorporating islamic messages in the english teaching in the indonesian context. International Journal Social and Science Education, 2(2), 157-165. Retrieved from http://ijsse.com/sites/default/files/issues/2012/Volume\%202\%20I ssue $\% 202 \% 20, \% 20 \% 202012 /$ Paper-16/Paper-16.pdf

Rosenthal, M. (2016). Qualitative research methods: why, when, and how to conduct interviews and focus groups in pharmacy research. Currents in Pharmacy Teaching and Learning, 8(4), 509-516. Retrieved from https://doi.org/10.1016/j.cptl.2016.03.021.

Sulistyo, G. (2011). Reading for meaning. Malang: Pustaka Kiaswara Press. 